\title{
2 \\ Warlpiri Ritual Contexts as Imaginative Spaces for Exploring Traditional Gender Roles
}

\section{Georgia Curran}

Stephen Wild's article 'Men as Women: Female Dance Symbolism in Warlpiri Men's Rituals' (1977-78) presents examples of men dancing in a way that imitates women. He argues that this is in part as a symbolic celebration of the complementarity of sex roles, and partly as a symbolic appropriation of women's procreative and nurturing role' (ibid.: 14) in which men are acting as 'substitute women' who are responsible for the 're-creation of Dreamtime ancestors', symbolically analogous to the physical creation of children by women - both 'necessary for the transgenerational continuity of [Warlpiri] society' (ibid.: 19). Despite widespread segregation between men and women in many facets of Aboriginal lives across Central Australia, which finds women largely associating with other women and their children, and adult men spending the majority of their time with other adult men, it is also evident that there is significant, though less obvious, inter-gender sharing of everyday material goods, responsibilities, and space, which largely centres on the obligations of kinship (Dussart 2000). In a ritual sphere, many of these particular gendered relations and roles are brought to the focus of attention and reinforced as the proper ways in which Warlpiri people should behave and engage with one another. In ritual contexts, culturally defined gendered behaviours and social roles are reconfirmed in a space 
where it is accepted to move outside the boundaries of social norms. This often takes the form of parody of behaviours associated with the opposite sex and is surrounded by hilarity, reinforcing the basis for these clearly defined gendered positions in the Warlpiri world.

Wild frames a central problem as 'why men dance in women's style in certain contexts of men's rites, but never the reverse' (1977-78: 14). In this chapter, I will explore some of the many components of Warlpiri women's rituals in which women parody men's behaviours and social roles. Whilst they do not dance in a men's style, there are many other ritual events that similarly serve to confirm the complementary nature of Warlpiri gender roles. My examples are drawn from my fieldwork in Yuendumu since 2005, mostly from a 15-month period from 2005 to 2008 in which I lived in Yuendumu and participated in women's rituals within the settlement as well as travelling with women from Yuendumu for ritual events in other Central Australian communities. My central argument in this chapter is that ritualised acts of parody provide an imaginative space in which Warlpiri people can safely explore beyond accepted gender roles, experimenting without the risk of moral and social consequence. In this space, they can address many of the key tensions and moral obligations that dominate most other areas of their lives. This kind of intellectual engagement with normally unquestioned aspects of a gendered identity works to further reinforce an overarching Warlpiri gendered morality.

In many ways, Wild's argument of 'symbolic appropriation of women's procreative roles' serves to reinforce many of the binary assumptions that were assumed in early ethnographic work in Central Australia. Heavily rooted in the traditionalised gender definitions of Western culture, this research assumed women's positions in the everyday domains of domestic work (childbearing and rearing, food preparation, etc.) and men in the more powerful intellectual roles surrounding ritual knowledge. Phyllis Kaberry advocated against this in her pioneering book Aboriginal Women, Sacred and Profane (1939), in which she demonstrated that women too have powerful ritual roles of their own, an understanding that emphasises 'complementarity and co-existence' (Dussart 2000: 8) between the sexes in a ritual sphere. Prior dichotomies had, however, become so entrenched that they did not become popular in scholarly research on Central Australian communities until the early 1980s (some examples include Bell 1983 and Hamilton 1981). Much of the ethnographic work in Warlpiri communities up until this time (Mervyn Meggit, Nancy Munn, and Olive Pink) worked with the assumption that men were the overseers 
and main contributors to ritual life, with women subjugated to a support role in the ritual realm. Meggitt's monograph The Gadjari among the Warlbiri Aborigines (1966) upholds this biased and dichotomised stance, likely influencing Wild in framing his understandings of the ways in which men imitate women dance styles in this ceremony.

The context in which Wild conducted his Warlpiri-based field research differs significantly from my own in several important ways that must be considered before our examples of men's and women's ritualised roles can be comparatively understood. First, our research was conducted in different Warlpiri settlements: Wild was based in Lajamanu, some 450 kilometres north of the Yuendumu, where I lived whilst undertaking my own fieldwork (and a greater distance again when driving along even the most directly accessible road between the two communities). Whilst the residents of these communities share parts of their ritual lives, often travelling to attend joint ceremonial events in other Warlpiri and Central Australian settlements, there are still distinctive differences in the rituals held in Lajamanu and Yuendumu. Wild's (1984) examination of the 'cultural semantics' of the Warlpiri Yam purlapa song series highlights some important northern influences in the Warlpiri musical styles in Lajamanu, which emphasise individual assertiveness and improvisation (also seen in Stubington 1978, and Clunies Ross and Wild 1987), despite its structural similarities to more conservative Central Australian musical styles (described with respect to the Pintupi and Alyawarr in Moyle 1979 and 1986). The Warlpiri songs that were central to my own Yuendumubased research did not show this kind of openness to improvisation, being more comparable to the conservative styles of close, neighbouring groups to the south. These observations indicate that Wild's examples of men's dance styles may have been more open to the individual dancer's input than some of the dance styles that I have documented from Yuendumu. Furthermore, important historical differences in the establishment of these settlements and the movements of Warlpiri people within them would have had an impact on the particular rituals that are held, as different family groups with associations to particular Dreamings and country have come to dominate the ritual life of each settlement.

A second consideration is the time period in which fieldwork was conducted. Wild's fieldwork was undertaken in a period from October 1969 through August 1972. My own fieldwork has been undertaken since 2005, some three-and-a-half decades later-a time of significant historical change for the Warlpiri residents of these communities. 
Increasing sedentarisation, alongside wage equality that saw Warlpiri people receive cash for the first time, rather than Superintendent-issued rations, has given increasing independence to Warlpiri people allowing participation in the cash economy and pursuit of material goods. This has included cars, which have had an enormous impact on distances travelled for ritual events (Peterson 2000), and the incorporation of money and shop-bought goods into the ritual payment system. The decline in knowledge of rituals and their associated songs and ceremonies is perhaps the most widely reported change in this time period. Additionally, in the ceremonies that are still held frequently such as the Kurdiji ceremony, there has been an expansion in the numbers of participants and scale of the ceremony (Curran 2011) — producing a kind of enhancement of these particular aspects of ritual life associated with the localised way in which Warlpiri people have engaged with modernity over the last few decades.

A third major difference that would clearly have had an enormous impact on the kinds of data that Wild and I have reported is our own personal gendered positions as researchers and the particular ways in which we would have participated in Warlpiri rituals and been told about ritual knowledge. As a man, Wild was incorporated into restricted areas of men's ritual activity (including the kajirri-Wild's Katjiri-which he refers to in his examples). Whilst Wild participated in rituals that included both men and women (and which he refers to in his 1977-78 article), it would have been unlikely that he participated in the private women's yawulyu events. It is also certain that he would not have been present for any of the raucous jiliwirri (joking around) that occurs in female-only contexts, such as when men travel in a group for part of a business event, ${ }^{1}$ or when women have been restricted from moving from a particular area due to the requirements of the ritual context. ${ }^{2}$ Wild's examples are largely drawn from the kajirri ritual (Katjiri in his text), which he argues is the clearest example of the theme of 'men as ritual procreators' (1977-78: 15). This ritual is no longer held in Warlpiri communities, but is remembered by many of the oldest generation of men. Other rituals that he refers to incorporate both men and women. The influence of Wild's maleness on the ritual contexts on which his research is based clearly shaped the contexts

1 An example is when men travel with initiation candidates, leaving the participating women near the ceremonial ground with the understanding that they will not leave the area until the men return.

2 For example, the Central Land Council organised women's 'business camps' in which many groups of women from across Central Australia would gather for a week to hold yawulyu. No men were allowed to attend these events, and they were held at an area prepared for this purpose in the bush. 
in which he draws examples of men dancing in women's style. Likewise, my own research was mostly with women, and in the instances where it was not, was certainly still from the vantage point of a woman. It is clear that the many instances in which I have documented women parodying men's roles are in contexts restricted to women, and Wild's examples of men dancing in female styles appear to have been in contexts restricted to men. These factors, as well as our individual decisions about how much of this information to publish and the particular opportunities that we have had to publish on particular aspects of our fieldwork experiences, likely combine to produce different data and different renderings of the data. Whilst there is significant inter-gendered sharing of ritual knowledge, it appears that it is in the context of private gender restricted rituals that Warlpiri people explore beyond the accepted gendered roles.

\section{Inter-gender sharing of ritual knowledge}

In her discussion on the nature of ritual secrecy, Dussart observes that 'the Warlpiri at Yuendumu seemed to transfer their ceremonial material via networks of kinship that accommodated, indeed revelled in, discrete expressions of cross-gender exchange' (2000: 59). She demonstrates the importance of kinship for the transfer of ritual knowledge-fitting into a body of feminist ethnographic writing that emphasises kinship connections over gendered divisions. As an example of this, Dussart demonstrates the importance of ritual knowledge shared between spouses, an observation that was to become pointed with respect to my own fieldwork where I worked closely with Thomas Jangala Rice and Jeannie Nungarrayi Egan, a husband and wife team (see Curran 2013 for details), recording and documenting details of the knowledge of many different genres of men and women's songs-even those that in other contexts may have been inappropriate for the opposite gender to attend. ${ }^{3}$ Within this context, Rice provided details of women's yawulyu songs that he remembered from when he was a young boy who spent his days with his mother and other women, demonstrating an obvious way in which men learn significant aspects of female ritual knowledge.

3 It should be noted here that the genres of restricted men's songs were certainly not appropriate for this research context. The kind of knowledge that we documented was also likely adapted for this male and female context. 
During my fieldwork, there were many other examples of contexts in which knowledge was discretely shared across opposite sex groups. During a ceremonial occasion in which 'men's business' was about to be held on the opposite side of the ceremonial ground, and women were busying themselves with other activities such as cooking, I was asked by one lady if I could drive her quickly to the shop. As we drove, she told me to hurry as we had to get back for the men's business. When I questioned whether the women were meant to be there for men's business, she responded in saying 'No, it's not for women, just for men-but we don't want to miss it!' (Gracie Napangardi Johnson, pers. comm., 2007). As the ritualised events occurred on the opposite side of the ceremonial ground, within muffled hearing range, the women busied themselves with other tasksemphasising the vital importance of 'not watching' men's business and obtaining a discrete knowledge of men's ritual affairs. Similarly, as the sun is setting during the marnakurrawanu rituals, key to the kurdiji ceremony, women 'pretend' that they are asleep as they lie in a north to south line of swags. The men sit directly to the east of their heads and sing loudly. Again it is of vital importance that women participate in this by 'not hearing or seeing' these men's songs. These kinds of contexts show how sharing of knowledge across sexes occurs frequently, although is not overtly acknowledged, and that women would learn significant areas of men's knowledge in the kinds of contexts often described as being restricted to men.

For the rest of this chapter, I would like to focus on some examples from my research of ways in which Warlpiri gender roles are ritually performed and reinforced, often parodying opposite gender roles. To do this, I will focus mostly on activities surrounding women's ritual. Preceding this, however, I will discuss the songs sung during the kurdiji ceremony, in which both men and women participate.

\section{Men's ritual roles as female Dreaming ancestors}

A core section of the rites that surround kurdiji is an all-night ceremony that begins at sunset and finishes at sunrise the next day, and marks the important social changes as a boy moves in to adulthood. Peterson has analysed part of this ceremony similarly, as a symbol of rebirth in which the mothers of the boys get up and circle around their sons, who are 
crouched down at the western end of the ceremony ground. These boys are decorated with white fluff that is removed from their heads at dawn and replaced with red ochre. Once the sun has fully risen they are covered from head to toe with red ochre and they walk back through the group of women to sit with the adult men on the far eastern side. Peterson has shown that this can 'be understood by the anthropologist as gestating in a womb and one identified with women, rather than appropriated by men' (2006: 6). He does note, however, that the extent to which the participants think of this in this way is difficult to determine. It is clear, however, that the Warlpiri participants do see this as a vital transition from a female-dominated social group to a male one-in the ceremony, they physically move from their position with women towards that with adult men. The songs that are sung over the all-night duration of this ceremony are the Karntakarnta song series - the journey of a group of ancestral women from a place in the far west of Warlpiri country towards the east. A group of senior and middle-aged Warlpiri men sit in a group looking towards the east as they sing these songs. Jeannie Nungarrayi Egan (pers. comm., 2008) explained whilst we were transcribing the words for the song series that is sung for this ceremony that these songs were 'sung by women in the Dreamtime but now only men can sing them'.

A short distance to the west of the men, a group of women dance and behind them, still further to the west, the boys who will transition into men crouch, protected by their ritual guardians (typically their brothersin-law). Warlpiri people clearly articulate that the ancestral women both sung and danced these same songs as they travelled across Warlpiri country, creating the places that they still exist within today. In the ceremonial context, men take on the voices of the female ancestors, which are oftentimes sung using first-person pronouns. Use of the first-person singular pronoun -rna throughout Warlpiri songs frames the singers as having the voice of the Dreaming ancestors, clearly differentiating performance of song from other everyday activities. The use of this pronoun in the following example indicates that the male singers are identifying with the female Dreaming ancestors, focal to the song.

Yamanarna japara wapa

Yamanarna japiri nguna

I am dancing with wide legs, eating as I move.

I am dancing with wide legs, eating as I stay still. 
In this song, the Dreaming women are depicted as dancing in the same 'dance jump' style (as described by Shannon 1971) that Wild (1977-78: 16) describes as a non-mimetic style of Warlpiri dance, characteristically performed by women. This style of dance, in its numerous elaborated forms is typically performed by women in larger public Warlpiri ceremonies that incorporate both men and women. This indicates that both men and women in kurdiji ceremonies are taking on the positions of the female Dreaming ancestors in contemporary ceremonial contexts: the men through singing from the perspective of the travelling women, and the women through dancing in the same style as they did whilst travelling across Warlpiri country.

In documenting the Warlpiri men's honey-ant love song, Wild (1990) has explained:

The song words constantly shift between subjective and objective points of view, as if the singer is sometimes taking the part of each character and at other times taking the part of an outside observer. This shifting perspective reflects the fact that the singer is both singing about ancestral events and participating in the ancestral events as an actor in the process of attracting a woman. (Wild 1990: 49-50)

These important linguistic mechanisms allow Warlpiri men to safely explore a female world and be empathetic to the gender-defined roles of women in Warlpiri society without risk of disrupting their own masculine form of sociality.

\section{Women's yawulyu}

Whilst in the rituals described above women dance in non-mimetic style, in many private contexts of women's yawulyu they do dance in the mimetic style described by Wild as 'mim[ing] the specific behavior of a Dreamtime ancestor. A mimetic dance has only as many dancers as there are characters in the Dreamtime incident being re-created' (1977-78: 16). For many of the yawulyu in which such mimetic dances are performed, the women sing from the perspective of male ancestral beings and dance in their roles, albeit in distinct female style. As a core group of owners sing, women who have inherited links to a particular Dreaming take on these roles, overseen by managers (of the opposing patrimoiety) and often their close cross-cousin, who have long established their roles as managers for that particular yawulyu. 
During my fieldwork, I saw the Warlukurlangu yawulyu performed on a number of occasions as part of 'finishing up' following the death of a senior woman who identified with this Dreaming. In this Dreaming story, two men of Jangala subsection run away from their evil Jampijinpa father, a blue-tongue lizard, who lit a raging bush fire in an effort to kill them (see Curran 2017 for further details of the story). In the yawulyu associated with this story, two women of Nangala and Nampijinpa subsections (together a patricouple) dance as the two Jangala men central to this story, adorned in red, white, and black ochre designs, white feathers, and strings of beads made from the seeds of the yinirnti 'bean tree'. The other female owners for this yawulyu sit in a group nearby and sing the songs, identifying also with the two Jangalas through song words that again frequently take a first-person perspective. Whilst parts of the dances are of the non-mimetic, 'dance jump' style described above, in which the dancers shuffle with their arms on their sides towards a ritual pole (kuturu), that is placed centrally on a ceremonial ground, they also dance in a style which directly mimes the two Jangalas as they bend down on their knees with their arms interlinked, as if dragging each other along, exhausted after running from the fire (see Figure 1).

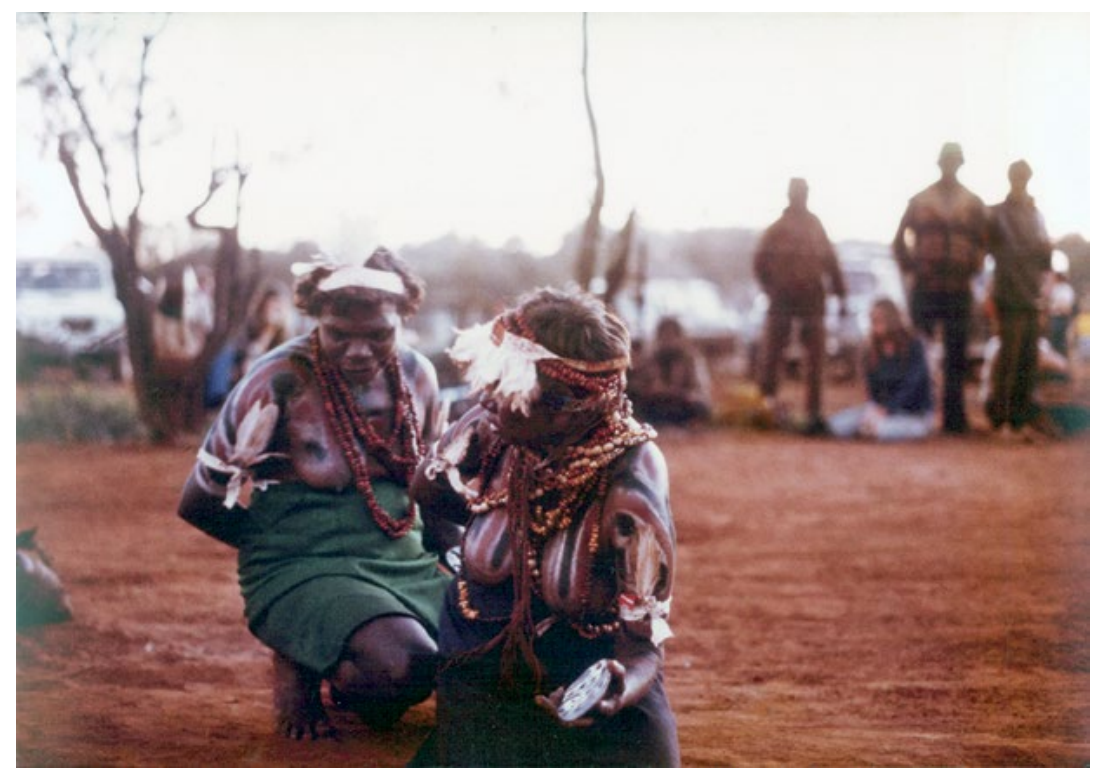

Figure 1. Judy Nampijinpa Granites and Rosie Nangala Fleming dance as the two Jangalas from the Warlukurlangu Dreaming, 1983

Source: Mary Laughren 
Whilst Wild argues that women do not perform mimetic dance movements in broader rituals that they perform alongside male singers, in the context of private, female yawulyu, they clearly do.

One of the most common situations in which women perform mimetic dance styles in which they take on the part of ancestral men is when visiting country associated with a particular song in a yawulyu song series. In the Ngarlu yawulyu, a Jungarrayi man pursues a woman of Napangardi subsection as she travels. Jungarrayi is of the wrong subsection to be a suitable marriage partner for Napangardi, making this very inappropriate behaviour. He succeeds, however, in seducing her by rolling hairstring at a groove in the rocks - the distinctive sound of this activity attracting her attention to this place. When I travelled to Ngarlu with a group of Warlpiri women, we sat down near the place where this Dreaming event occurred (see Figure 2). Two women sat facing each other, one of Nungarrayi subsection, who performed the part of the male equivalent of her subsection, Jungarrayi, and one of Napangardi subsection, who appropriately played the Napangardi woman. As the other three women sang the Ngarlu yawulyu songs, Nungarrayi mimicked the way in which Jungarrayi was rolling hairstring, and Napangardi edged towards her in the groove in the rock. As she got close, Nungarrayi captured Napangardi dramatically. This was followed by fits of laughter from all the women present - the hilarity being typical of these kinds of mimetic dances where women act in the part of men.

Similarly, when I was working with a group of Warlpiri women documenting the Jardiwanpa yawulyu song series (Gallagher et al. 2014), we reviewed our book proofs that already included our transcriptions of the words of the songs. As we worked to further explicate the meanings of these songs, the women performed several mimetic dances in which the women played the parts of male Dreaming ancestors. The Jardiwanpa story centres on the male character Yarripiri, an ancestral inland taipan, who comes out from the ground at Wirnparrku near Haasts Bluff and travels northwards, creating places as he travels and morphing himself into other Dreaming ancestors as he goes through different country. In Figure 3, Coral Napangardi Gallagher dances in the role of Yarripiri as he travels northwards, taking on the wide-eyed, blank stare of men's mimetic dances in which they filter out engagement with onlookers. Gallagher's poignant depiction of a male dance again producing laughter amongst the rest of the group of women. 


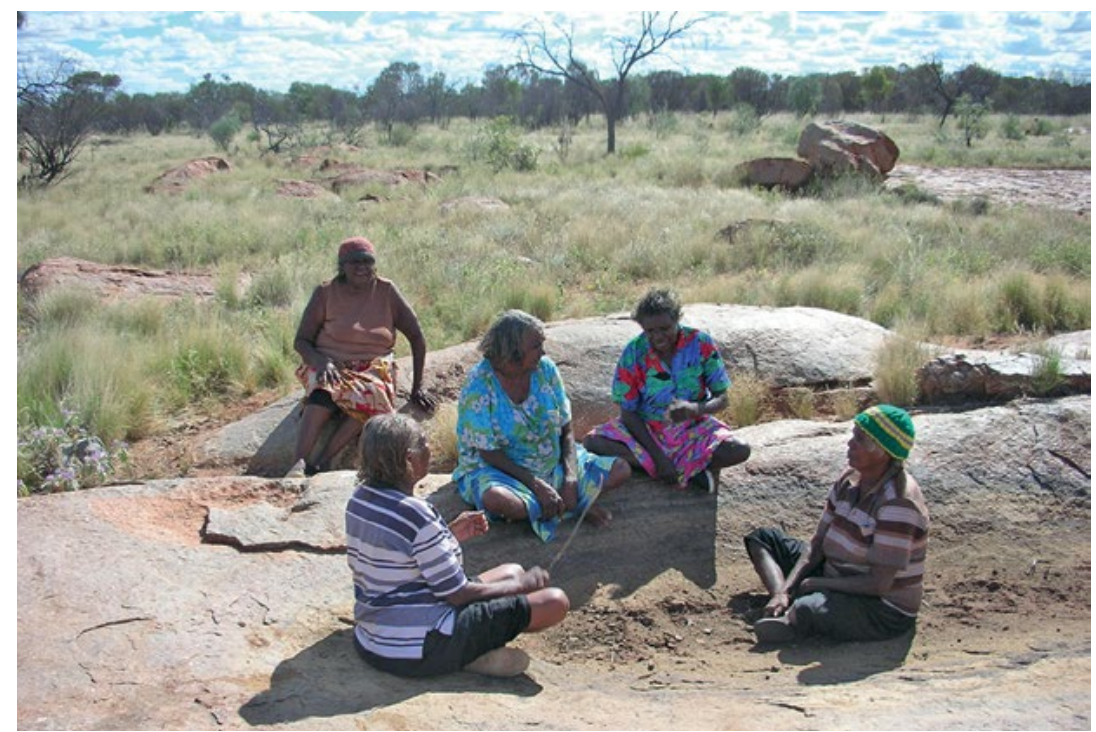

Figure 2. Clockwise from top left: Ruth Napaljarri Oldfield, Mavis Nampijinpa, Topsy Napaljarri, Emma Nungarrayi (as Jungarrayi), and Coral Napangardi Gallagher (as Napangardi) enact the seduction of two wrong-way marriage partners at Ngarlu, 2006

Source: Georgia Curran

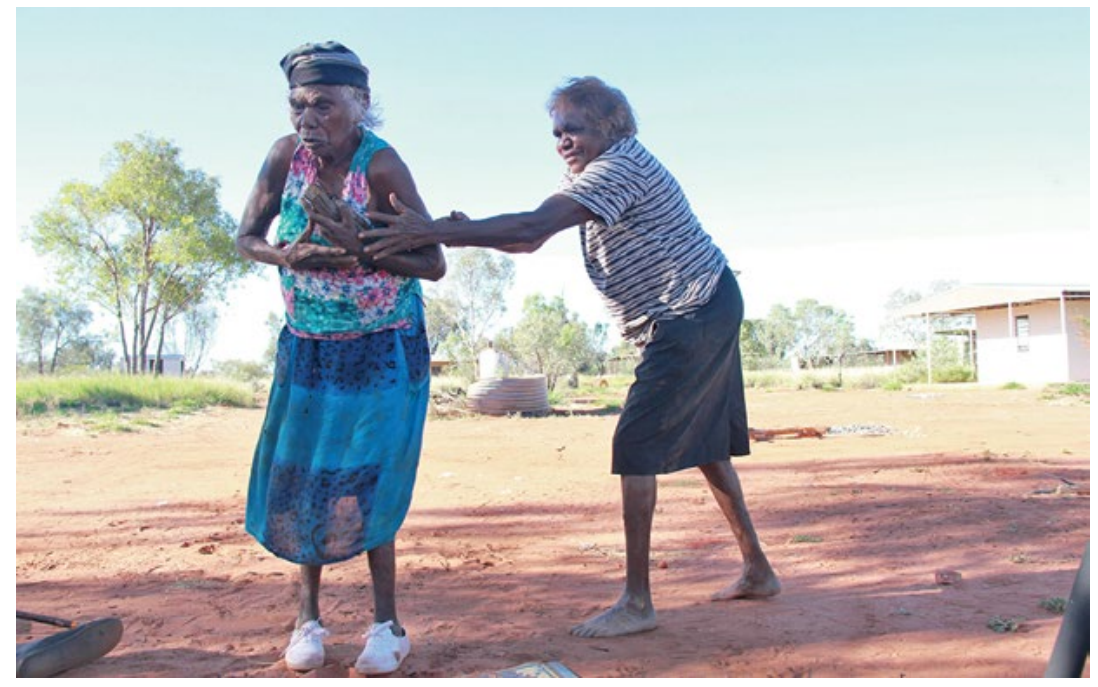

Figure 3. Coral Napangardi Gallagher dances in the male role of Yarripiri, the ancestral inland taipan as he travels northwards through Warlpiri country, 2014

Source: Margaret Carew 
In each of these yawulyu, women take on the role of male Dreaming ancestors and dance in the mimetic style that Wild attributes to men. Interestingly, in Wild's accounts, the men dance in this way depicting female Dreaming ancestors and women's ways of dancing. In these examples from women's yawulyu dances, the opposite seems apparent, with women dancing in the mimetic style associated with men-the larger purpose of this appears to be the hilarity of women taking on these male roles. Whilst it is common for women to do this in private contexts when they are singing one or two yawulyu songs, in a ceremonial context (such as that of the Warlukurlangu yawulyu described above) this kind of jiliwirri 'joking around' would be highly inappropriate.

\section{Jiliwirri 'joking around'}

Yasmine Musharbash (2008) has explored Warlpiri humour, drawing on Freud's theories of laughter as a kind of anxiety release (1916 [1905]). In the contexts outlined above, the strictness of adhering to traditional gendered roles that dominate most of Warlpiri life are loosened such that both men and women appear to have a context in which to explore gendered boundaries and gain empathy for the roles of the opposite sex. As these contexts sharply contrast with the more usual strict gender roles of everyday life, the discomfort felt in these situations is released in laughter.

Ken Hale (1971) has written about a men's ritual language called jiliwirri or 'up-side-down Warlpiri'. This is a language that men learn in an exclusively male phase of initiation (which is no longer performed) and is, therefore, inappropriate to discuss with Warlpiri women or children. Hale describes the general rule for speaking this language as follows: 'replace each noun, verb, and pronoun of ordinary Warlpiri by an "antonym"' (1971: 473). He gives some obvious examples of antonymy; he also provides several examples that indicate that an antonym is derived from something of a similar taxonomic group, for example, the jiliwirri for 'mulga tree' is 'witchetty bush', or the jiliwirri for 'blood' is 'urine'. This language clearly gets more interesting as other more abstract semantic domains come into the picture. Hale summarises that:

The jiliwirri principle of antonymy is semantically based i.e. the process of turning Warlbiri 'up-side-down' is fundamentally a process of opposing abstract semantic objects rather than a process of opposing lexical items in the grossest and most superficial sense. (Hale 1971: 477) 
During ceremonial gatherings that I attended in Yuendumu, a practice also called jiliwirri was performed in an exclusively female realm. This involves raucous joking around, exaggerating the actions of men to the point where often everyone would be in stitches of laughter. Certain women were renowned for 'making jiliwirri' and were often the centre of these events. This type of behaviour occurred even more often in highly restricted women's groups. In one such ceremonial gathering in the community of Mt Allan in 2006, all men present informed the group of women that they were going in to the bush to hold a particular male-only section of the business surrounding initiation. After a safe period when they were assuredly out of sight, the women began to dance around mockingly in parnpa (restricted men's song genre) style, with red headbands similar to those that the men wear for business. When the men returned there was a panic to get rid of these so that the men would not see what we were doing. Like the jiliwirri language that Hale described, this behaviour was also about turning upside-down' the normal roles of women in Warlpiri society. These examples from the performance and song texts of the kurdiji ceremony demonstrate clearly Dussart's (2000) point that male and female realms are not exclusive, and that there is a large degree of sharing of knowledge between these groups. It is the ways in which this knowledge is shared that clearly mark the differentiation between male and female realms.

Another instance in which the Warlpiri appreciation for the distinct gendered nature of social roles is clear is in the appreciation for Aboriginal comedian Mary G, a cross-dressing man, who visited Yuendumu to perform as part of a concert for the annual Sports Weekend in 2006. By far one of the biggest hits of the night, Mary G had an easy audience amongst Warlpiri people at Yuendumu. A man performing as a woman, served a similar purpose in temporarily transforming typical gendered roles, giving Warlpiri people a safe, happy, and accepted space in which to explore the roles of the opposite sex.

In Michael Jackson's interpretation of Kuranko narratives, he discusses the power of an individual narrative to explore the ambiguities of social life, noting that:

Kuranko narratives establish an initial situation that is ambiguous. The boundaries which ordinarily define significant social categories or groups are blurred. Distinctions are annulled. Symbols that are usually kept apart are merged. This deliberate and systematic obfuscation generates ethical dissonance; it heightens affect, increases anxiety, promotes ambivalent attitudes, and inspires the listeners to reduce the ambiguity. (Jackson 1982: 2) 
My argument in this chapter has been that the domain of Warlpiri ritual, distinct from everyday life, also forms a space in which people can question, explore, and stretch the otherwise dominant social roles. In this context, it gives Warlpiri people a space in which to imagine a world that does not have the segregated gendered positions that they regularly live by. 'Wrong way' love affairs present a threat to the social order of Warlpiri life in which a carefully balanced system for marriage relationships dominates the right and moral way in which to live. These affairs are, however, common in the Dreaming stories that recount the actions of ancestral beings. Similarly the jiliwirri associated with restricted female ritual contexts, often depicting women in men's roles, incites fear in 'turning up-side-down' accepted social roles, anxieties surrounding this being released in the form of laughter.

I began this chapter by outlining Wild's (1977-78) twofold explanation for why men dance in women's styles in Warlpiri ritual: first as a 'celebration of the complementarity of sex roles' and second as 'a symbolic appropriation of women's procreative and nurturing role' (ibid.: 14). Ritual is clearly a forum for significant sharing of gendered knowledge. In providing a space in which Warlpiri people can imagine the world of the opposite sex, they have a safe space in which to experiment with the rules of their social worlds. Many of the tensions and ambiguities of their social roles can be explored without pushing past the accepted moral terms, ultimately re-confirming traditional gender roles and the subsequent social segregation of men and women in Warlpiri communities.

\section{References cited}

Bell, Diane. 1983. Daughters of the Dreaming. Sydney: McPhee Gribble and George Allen Unwin.

Clunies Ross, Margaret, and Stephen A. Wild. 1987. 'Research into Aboriginal Songs: The State of the Art.' In Songs of Aboriginal Australia, edited by Margaret Clunies Ross, Tamsin Donaldson, and Stephen A. Wild, 1-13. Sydney: University of Sydney Press.

Curran, Georgia. 2011. 'The "Expanding Domain” of Warlpiri Initiation Ceremonies.' In Ethnography and the Production of Anthropological Knowledge: Essays in Honor of Nicolas Peterson, edited by Yasmine Musharbash and Marcus Barber, 39-50. Canberra: ANU E Press. 
. 2013. 'The Dynamics of Collaborative Research Relationships: Examples from the Warlpiri Songlines Project.' Collaborative Anthropologies 6: 353-72. doi.org/10.1353/cla.2013.0016.

—_. 2017. ed. Yurntumu-wardingki juju-ngaliya-kurlangu yawulyu: Warlpiri Women's Songs from Yuendumu. Darwin: Batchelor Press.

Dussart, Françoise. 2000. The Politics of Ritual in an Aboriginal Settlement: Kinship, Gender and the Currency of Knowledge. Washington: Smithsonian Institution Press.

Freud, Sigmund M. 1916 [1905]. Wit and Its Relation to the Unconscious. New York: Moffat, Yard and Co.

Gallagher, Coral, Peggy Brown, Georgia Curran, and Barbara Martin. 2014. Jardiwanpa yawulyu: Warlpiri Women's Songs from Yuendumu. Darwin: Batchelor Press.

Hale, Kenneth. 1971. 'A Note of a Walbiri Tradition of Antonymy.' In Semantics: An Interdisciplinary Reader in Philosophy, Linguistics and Psychology, edited by D. D. Steinberg and L. A. Jokobovitz, 472-82. Cambridge: Cambridge University Press.

Hamilton, Annette. 1981. 'A Complex Strategical Situation: Gender and Power in Aboriginal Australia.' In Aboriginal Women, edited by Norma Grieve and Patricia Grimshaw, 69-85. Melbourne: Oxford University Press.

Jackson, Michael. 1982. Allegories of the Wilderness: Ethics and Ambiguity in Kuranko Narratives. Bloomington: Indiana University Press.

Kaberry, Phyllis. 1939. Aboriginal Women, Sacred and Profane. London: Routledge.

Meggitt, Mervyn. 1966. The Gadjari among the Warlbiri Aborigines. Oceania Monographs. Sydney: University of Sydney Press.

Moyle, Richard. 1979. Songs of the Pintupi: Musical Life in a Central Australian Society. Canberra: Australian Institute of Aboriginal Studies.

—_. 1986. Alyawarr Music. Canberra: Australian Institute of Aboriginal Studies. 
Musharbash, Yasmine. 2008. 'Perilous Laughter: Examples from Yuendumu, Central Australia.' Anthropological Forum 8 (3): 271-77. doi.org/10.1080/00664670802429388.

Peterson, Nicolas. 2000. 'An Expanding Domain: Mobility and the Initiation Journey.' Oceania 70: 205-18. doi.org/10.1002/j.18344461.2000.tb03019.x.

— 2006. 'How Literally Should Warlpiri Metaphors Be Taken?' Paper presented at 'Critical Intersections, Ethnographic Analyses and Theoretical Influence: In Honour of Nancy Munn', American Anthropological Associations Annual Meetings, San Jose, California, USA, 15-19 November.

Shannon, Cynthia. 1971. 'Warlpiri Women's Music: A Preliminary Study.' BA (Hons) thesis, Monash University, Melbourne.

Stubington, Jill. 1978. Yolngu Manikay: Modern Performances of Australian Aboriginal Clan Songs. Clayton: Monash University.

Wild, Stephen A. 1977-78. 'Men as Women: Female Dance Symbolism in Warlbiri Men's Rituals.' Dance Research Journal 10 (1): 14-22. doi.org/10.2307/1478492.

—. 1984. 'Warlbiri Music and Culture: Meaning in a Central Australian Song Series.' In Problems and Solutions: Occasional Essays in Musicology Presented to Alice M. Moyle, edited by Jamie C. Kassler and Jill Stubbington, 186-203. Sydney: Hale and Iremonger.

— 1990. 'A Central Australian Men's Love Song.' In The Honey-ant Men's Love Song and Other Aboriginal Song Poems, edited by R. M. W. Dixon and Martin Duwell, 49-69. St Lucia: University of Queensland Press. 
This text is taken from A Distinctive Voice in the Antipodes: Essays in Honour of Stephen A. Wild, edited by Kirsty Gillespie, Sally Treloyn and Don Niles, published 2017 by ANU Press, The Australian National University,

Canberra, Australia.

dx.doi.org/10.22459/DVA.07.2017.02 